\title{
CROSS-TOLERANCE MECHANISM INDUCTION IN MELON SEEDS BY PRIMING PRIOR DRYING
}

\author{
Indução do mechanismo de tolerância cruzada em sementes de \\ melão osmoticamente condicionadas antes da secagem
}

Jean Marcel Sousa Lira ${ }^{1}$, Túlio Silva Lara², Amanda Cristiane Rodrigues ${ }^{2}$,
Sara Dousseau ${ }^{3}$, Marcelo Murad Magalhães ${ }^{4}$, Amauri Alves de Alvarenga ${ }^{2}$

\begin{abstract}
The loss of benefits after re-drying is one of the drawbacks of the seed priming technique. Different types of stresses have been used before re-drying to preserve the priming benefits. This process may be seen as promoting cross tolerance to increase the defense mechanisms that prevent loss of viability in seeds primed after drying. We tested the effect of some stresses to induce cross-tolerance and different drying conditions with the aim of maintaining priming benefits in melon seeds. The seeds were primed in an aerated $\mathrm{KNO}_{3}$ solution $(0.35 \mathrm{M}),-1.7 \mathrm{MPa}, 25^{\circ} \mathrm{C}$, in the dark for six days. The primed seeds were then submitted to slow drying, fast drying, cold shock + slow drying, cold shock + fast drying, heat shock + slow drying, heat shock + fast drying, PEG + slow drying, PEG + fast drying, ABA + slow drying, ABA + fast drying and no drying (planted directly after priming). We evaluated antioxidant enzyme activities (SOD, CAT and APX), germinability, mean time of germination (MTG) and mean rate of germination (MRG). A completely randomized design was used with three repetitions of 50 seeds in each treatment. Data were analyzed by ANOVA and means were compared by the Scott-Knott test $(p \leq 0.05)$. ABA increased SOD activity after drying and CAT activity was reduced by priming. APX activity was not observed. The stress submission prior to re-drying improved the MRG and reduced MTG. Therefore, the induction of the cross-tolerance mechanism could be effective to maintain priming benefits in melon seeds.
\end{abstract}

Index terms: PEG; priming; dry seeds; antioxidant system.

\section{RESUMO}

A perda dos benefícios do condicionamento, após a ressecagem, é um dos problemas do condicionamento. Para conservar os benefícios, têm sido utilizados diferentes estresses antes da secagem. Esse processo poderia agir como tolerância cruzada, aumentando os mecanismos de defesa, prevenindo a perda de viabilidade em sementes condicionadas após a secagem. Assim, testou-se o efeito de estresses, na tentativa de induzir tolerância cruzada, após diferentes secagens, mantendo os benefícios do condicionamento em sementes de melão. Dessa forma, as sementes foram condicionadas em solução aerada de $\mathrm{KNO}_{3}(0,35 \mathrm{M})$, $-1,7 \mathrm{MPa}, 25^{\circ} \mathrm{C}$, no escuro, por seis dias. Depois disso, foram submetidas à secagem lenta, rápida, choque de frio + secagem lenta e rápida, choque de calor + secagem lenta e rápida, $\mathrm{PEG}+$ secagem lenta e rápida, $\mathrm{ABA}+$ secagem lenta e rápida e sementes sem secagem. As sementes não condicionadas foram o controle. Foi avaliada a atividade das enzimas SOD, CAT e APX, germinabilidade, tempo médio de germinação e taxa média de germinação. O delineamento experimental utilizado foi inteiramente casualisado (DIC) com três repetições, contendo 50 sementes para cada tratamento. Para a análise estatística dos dados, foi utilizado ANOVA e as médias comparadas pelo teste de Scott-Knott $(\mathrm{p} \leq 0,05)$. A aplicação de ABA aumentou a atividade da SOD após a secagem e o condicionamento reduziu a atividade da CAT. O estresse inicial, antes da secagem, aumentou- a e reduziu o tempo médio de germinação. Contudo, a indução do mecanismo de tolerância cruzada pode ser efetiva na manutenção dos benefícios do condicionamento.

Termos para indexação: PEG; condicionamento; sementes secas; sistema antioxidante.

\section{INTRODUCTION}

The brazilian fruit production is characterized by a wide diversity of products, of which only a small part is sold internationally on a large scale. According to data from the Brazilian Institute of Fruits - IBRAF (2013), fruit production in Brazil is approximately 43.6 million, and covers an area of 2.2 million hectares.
Brazil is currently the world's third-largest producer of fruit after China and Turkey. In international markets, Brazil's fruit industry occupies an important position by exporting $693000 \mathrm{t}$ fresh fruit per year. The melon (Cucumis melon L.) is the fresh fruit with highest exported volume (almost 182 thousand tonnes) in Brazil (IBRAF, 2013).

Melon is a species of the Cucurbitaceae family and has low germination and growth at both low temperatures

\footnotetext{
${ }^{1}$ Universidade Federal de Lavras/UFLA - Cx. P. 3037 - 37200-000 - Lavras - MG - Brasil - lirajms@posgrad.ufla.br

2Universidade Federal de Lavras/UFLA - Lavras - MG - Brasil

${ }^{3}$ Centro Regional de Desenvolvimento Rural Centro Norte/CRDR Centro Norte - Linhares - ES - Brasil

${ }^{4}$ Empresa Brasileira de Pesquisa Agropecuária/EMBRAPA - Amazônia Oriental - Belém - PA - Brasil

Received in september 21, 2014 and approved in november 21, 2014
} 
(below $13{ }^{\circ} \mathrm{C}$ ) and high ones (above $40{ }^{\circ} \mathrm{C}$ ) (Edelstein; Nerson, 2009). This is a problem to melon cultivations in northwestern and southern Brazil. As a result, priming of melon seeds has been used to increases germination and vigor under stressful conditions (e.g., low temperature, high temperature, drought, high salinity, etc.) (Farooq et al., 2007; Nascimento, 2005; Farhoudi; Saeedipour; Mohammadreza, 2011).

Priming is a treatment used to improve seed performance under stressful environmental conditions (Ashraf; Foolad, 2005). Seed germination performance (germination rate, germination time and plant uniformity) is very important for successful production of melons in these areas because seeds are occasionally sown under unfavorable temperature conditions due to the local climate.

Priming of melon seeds with $\mathrm{KNO}_{3}$ (potassium nitrate) was observed to improve germination rate, germination speed, homogeneity of plants and invigoration (Nascimento; Aragão, 2002). However, primed melon seeds cannot be stored due to their high moisture, requiring them to be adequately dried before storage (Butler et al., 2009). But this subsequent drying can reduce or eliminate the priming benefits as a consequence of germination having advanced to a state of lost desiccation tolerance (Sliwinska; Jendrzejczak, 2002), making them more susceptible to damage during dry storage (Powell et al., 2000). The temperature and duration of drying after priming affected the vigor and viability of melon seeds (Nascimento; West, 2000).

The effect of priming, particularly with respect to maintenance of benefits and subsequent longevity, can be influenced by the conditions immediately after priming (Butler et al., 2009). Seeds dried at different rates (slow or fast) after priming showed differential gene expression, similar to what occurs with genes that act to protect DNA and promote tolerance to stress (Soeda et al., 2005).

Drying of seeds that have partially lost desiccation tolerance imposes stress, and the resultant injury varies according to drying speed. Primed seeds inevitably endure some injury by the drying to tolerate subsequent stress (Chen; Arora, 2013). Together with drying after priming, low and high temperature, water stress and abscisic acid (ABA) can be used to maintain priming benefits (Lin et al., 2005; Sabehat; Lurie; Weiss, 1998). Drying after priming might work as a cross-tolerance mechanism to activate the seed defense system to subsequent severe stress (Genoud; Metraux, 1999; Kranner et al., 2010).

The antioxidant system is regarded as one of the major defense systems in seeds, operating through enzymatic and non-enzymatic pathways by scavenging reactive oxygen species (ROS) (Chen; Arora; Arora, 2010).
The detoxifying mechanisms play an important role in acquisition of desiccation tolerance, completion of seed germination and seed storability (Bailly, 2004).

Thus, the aim of this study was to evaluate the effects of slow and fast-drying associated or not with low and high temperature, water stress and ABA after priming, to promote cross-tolerance and improve antioxidant system activity and maintain priming benefits in melon seeds.

\section{MATERIAL AND METHODS}

\section{Plant material and priming}

Melon seeds (Cucumis melon cv.), cv. Hales Best Jumbo, were purchased from Feltrin Co. Ltd. and submitted to priming in $0.35 \mathrm{M} \mathrm{KNO}_{3}$. During priming, the seeds were maintained under continuous aeration at $20{ }^{\circ} \mathrm{C}$ in the dark for six days (Nascimento, 2004). The primed seeds were then washed twice with distilled water and dried to original moisture content $(7.0 \%)$ through different treatments before performing germination tests.

\section{Treatments for cross-tolerance induction}

The cross-tolerance mechanism was induced using a combination of eight stress conditions: cold shock (CS) + slow drying (SD); cold shock + fast drying (FD); heat shock (HS) + slow drying; heat shock + fast drying; PEG + slow drying; $\mathrm{PEG}+$ fast drying; $\mathrm{ABA}+$ slow drying; and $\mathrm{ABA}+$ fast drying. Besides these combination of factors, as control we formed groups subjected to slow drying, fast drying, no drying as well as unprimed seeds.

Cold shock treatments were at $1{ }^{\circ} \mathrm{C}$, while for heat shock the seeds were submitted to $45^{\circ} \mathrm{C}$, for two hours in both treatments. Drought stress was imposed with PEG (6000), $-1.7 \mathrm{MPa}$, at $5{ }^{\circ} \mathrm{C}$ in the dark for three days (Buitink et al., 2003; Faria et. al. 2005). Hormo-priming consisted of using $10 \mu \mathrm{M} \mathrm{ABA}$ (Vieira et al., 2010).

To slow dry the seeds, we used an open top plastic pot lined with paper towel, at room temperature of $25^{\circ} \mathrm{C}$ and $50 \% \mathrm{RH}$ (relative humidity), to reach the initial seed water content (about 24 hours) of 5-7 $\mathrm{gH}_{2} \mathrm{O} \mathrm{g} \mathrm{DM}^{-1}$. Fast drying was performed in a flow chamber, temperature of $32{ }^{\circ} \mathrm{C}$, until initial water content (about 2 hours).

\section{Antioxidant activity}

SOD activity was measured by the method described by Giannopolitise and Ries (1977), adapted for tomato seed analysis. The assay mix included: $50 \mathrm{mM}$ potassium phosphate buffer $(\mathrm{pH}=7.8), 14 \mathrm{mM}$ methionine, $75 \mu \mathrm{M}$ nitro blue tetrazolium, $2 \mu \mathrm{M}$ riboflavin, $100 \mathrm{nM}$ EDTA and $20 \mu 1$ enzyme extract. Reaction was initiated by adding riboflavin and placement under fluorescent light $(15 \mathrm{~W})$, and 
was allowed to continue for $40 \mathrm{~min}$, when it was ended by switching off the light and covering the tubes with a black cloth. Subsequently, the absorbance of the mixture was measured at $560 \mathrm{~nm}$ with a Biotek Epoch spectrophotometer. One unit of SOD activity was defined as the amount of the enzyme required to reach $50 \%$ inhibition of the reaction in the "minus enzyme extract" control, which should have a higher absorbance compared to the samples with enzyme extract.

CAT activity was measured using the protocol Havir and McHale (1987). The assay mix included $200 \mathrm{mM}$ potassium phosphate buffer (pH 7.0), $20 \mu$ l enzyme extract, and $120 \mu 112.5 \mathrm{mM} \mathrm{H}_{2} \mathrm{O}_{2}$ solution. One unit CAT activity was defined as the degradation $1 \mu \mathrm{M} \mathrm{H}_{2} \mathrm{O}_{2}$ during one minute at $240 \mathrm{~nm}$ (using extinction coefficient $\varepsilon=36 \mathrm{mM}^{-1} \mathrm{~cm}^{-1}$ ).

APX activity was measured using the protocol of Nakano and Asada (1981) modified for tomato seeds. The assay mix was composed of $50 \mathrm{mM}$ potassium phosphate buffer ( $\mathrm{pH} 7.0$ ), $0.5 \mathrm{mM}$ ascorbic acid (ASA), $0.1 \mathrm{mM}$ EDTA, $20 \mu \mathrm{l}$ enzyme extract. $\mathrm{H}_{2} \mathrm{O}_{2}(0.1 \mathrm{mM})$ was added to initiate the reaction. One unit of APX was defined as the conversion of ASA $(1 \mu \mathrm{M})$ into the monodehydroascorbate at $290 \mathrm{~nm}$, during one minute $\left(\varepsilon=2.8 \mathrm{mM}^{-1} \mathrm{~cm}^{-1}\right)$.

\section{Measurements of the germination process}

Four replications containing 50 seeds were used as samples. Measurements were performed on paper rolls using Germitest ${ }^{\circledR}$ paper. The rolls were moistened with distilled water and placed in a germination chamber at 25 ${ }^{\circ} \mathrm{C}$. The number of germinated seeds was recorded daily for seven days. Each seed was considered germinated when its radicle reached $2 \mathrm{~mm}$. At the end of this period, germinability $(\mathrm{G} \%)$, mean germination time $(\mathrm{t})$, and mean germination rate (v) were calculated (Ranal et al., 2009).

\section{Statistical design}

The experiment was completely randomized with four replications and 50 seeds per replicate for each treatment. The data on antioxidant activity and germination were subjected to the Shapiro-Wilk test and analysis of variance (ANOVA). The differences between the means were compared using the Scott-Knott test $(\mathrm{P}<0.05)$.

\section{RESULTS AND DISCUSSION}

\section{Antioxidant activity}

The antioxidant activity was evaluated through enzymatic activity. The SOD activities of the re-dried seeds were similar to those of the control seeds. Only priming seeds with ABA increased SOD activity after drying (slow or fast) (Figure 1).
The activity increase in SOD can be seen as a crosstolerance effect induced by ABA. This phytohormone is involved to signaling the accumulation of stress proteins (LEAs and HSPs) and antioxidant system (Baxter; Mittler; Suzuki, 2013), related to protection of the membrane for desiccation tolerance (Catusse; Job; Job, 2008). Moreover, the priming with $\mathrm{ABA}$ can act as a cross-tolerance activating defense system of seeds to drying. Just as in desiccation tolerance, increased activity in SOD triggered by ABA leads to a reduction in ROS levels and consequently less damage to the membrane structure when submitted to water loss (Eisvand et al., 2010). As a result, such seeds should maintain vigor and priming benefits after drying. The priming in melon seeds reduced CAT activity in relation to the control seeds (unprimed) (Figure 2). The lower CAT activity in primed seeds may be due to less ROS production or activation of non-enzymatic antioxidant pathways.

In dry seeds the non-enzymatic antioxidant system plays a more important role than the enzymatic system (Bailly, 2001). Thus, priming associated with stress and ABA could lead to increase of antioxidant molecule synthesis, reducing CAT activity and improving the seed germination performance after re-drying.

The priming with PEG with low osmotic potential (drought simulation) was the only priming treatment that had a smooth increased in CAT activity. This may have been because melon seeds under drought stress increase their antioxidant activity (Farhoudi; Saeedipour; Mohammadreza, 2011).

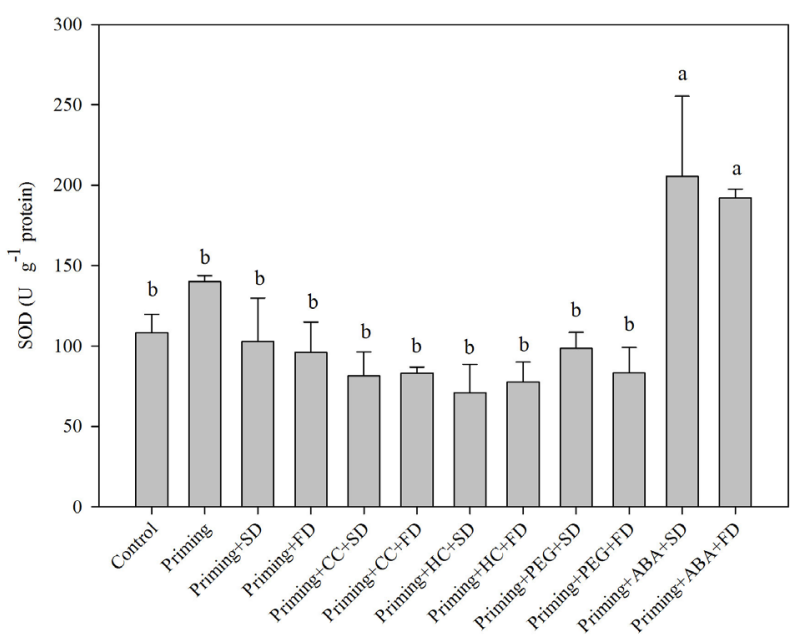

Figure 1: Mean values and standard errors for superoxide dismutase (SOD) activity in melon seeds observed under different conditions.

Means were compared by the Scott-Knott test. 


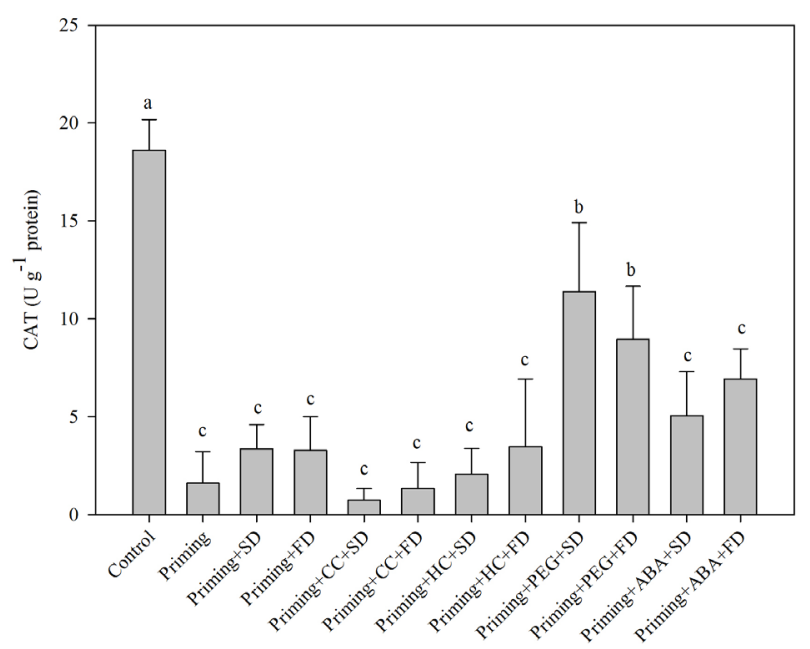

Figure 2: Mean values and standard errors for catalase (CAT) activity in melon seeds observed under different conditions.

Means were compared by the Scott-Knott test.

Of the enzymes tested only APX did not show activity. In some cases, this may have been due to the complex action mechanism of ascorbate-glutathione cycle, which in dry seeds is not activated (Bailly, 2001).

\section{Measurements of the germination process}

The priming reduced germinability in relation to control, and cross-tolerance treatment improved germinability (Figure 3).Among the cross-tolerance treatments, only priming $+\mathrm{ABA}+\mathrm{SD}$ did not improve germinability (G\%) when compared with the control.

In seeds with high vigor, priming can reduce germinability (Bray, 1995). For tomato, carrot and asparagus seeds, beneficial effects of priming were observed only for low-vigor seeds (Alvarado; Bradford, 1988a; 1988b; Cantliffe; Elballa, 1994; Bittencourt et al., 2004). Priming of melon seeds increased germination performance in seeds of with low vigor (Nascimento, 2004).

The germinability improvement observed in the cross-tolerance treatment may be related to a possible drop of ROS concentration and consequently lower CAT activity, as observed in the seeds submitted the cross-tolerance treatment. The higher the scavenging capacity of ROS in seeds, the larger the germinability will be (Lara et al., 2014).

The positive effect on the germinability was not observed for the priming $+\mathrm{ABA}+\mathrm{SD}$ treatment. Although ABA treatment increased SOD activity, treatment with ABA plus slow drying led to reduction in germinability. This can partially be explained by the dormancy effect induced by
ABA (Catusse et al., 2008) and by fewer germinated seeds because of the increased germination time $(\mathrm{t})$ and reduced germination rate (v). However, fast drying appears to have softened the dormancy effect induced by ABA.

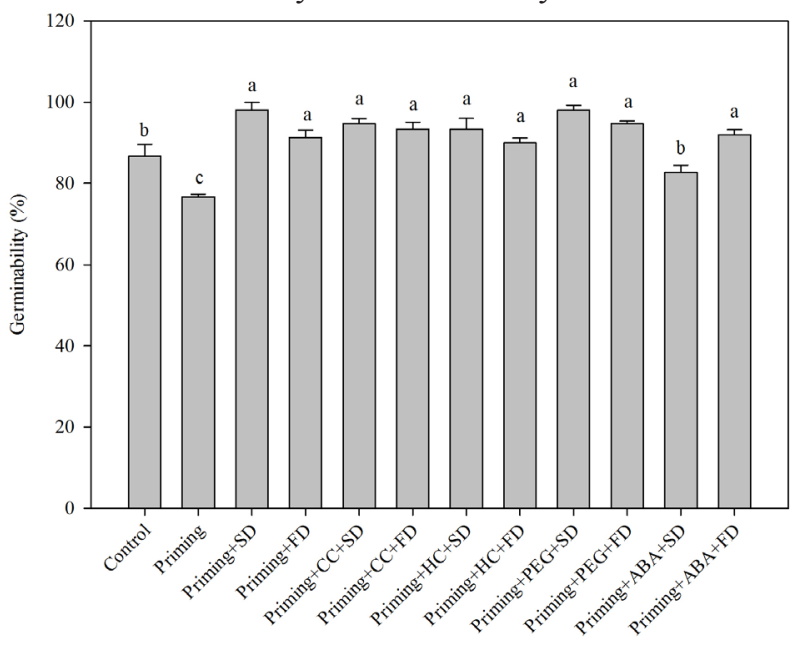

Figure 3: Mean values and standard errors for germinability $(\% \mathrm{G})$ of melon seeds observed for different conditions. Means were compared by the Scott-Knott test.

In general, the cross-tolerance treatment reduced mean germination time $(t)$ and increased mean germination rate (v) of melon seeds (Figure 4).

Slow drying appears to have the strongest effects regarding improved germination time $(\mathrm{t})$ and germination rate (v). We observed that slow drying was able to enhance these effects when applied after application of other stresses.

Slow drying after priming in the temperature range 20-30 ${ }^{\circ} \mathrm{C}$ seems not to decrease the activity of antioxidant enzymes such as superoxide dismutase, catalase and peroxidase (Sedghi, 2013). Thus, seeds which were dried slowly remained with a more active antioxidant system. Furthermore, slow drying has been found to be correlated with increases in chaperon protein levels (Lin et al., 2005). However, it seems that drought stress may maintain activity of antioxidant enzymes after fast drying. Considering the desiccation tolerance of seeds, when they were subjected to water stress beforehand, they maintained their viability afterward (Buitink et al., 2003).

As previously shown, ABA improved SOD activity and maintained germinability. Nevertheless, melon seeds with ABA cross-tolerance treatment had longer mean germination time and lower mean germination rate. These reactions may have been due to the dormancy effect of ABA, leading to slower germination. 

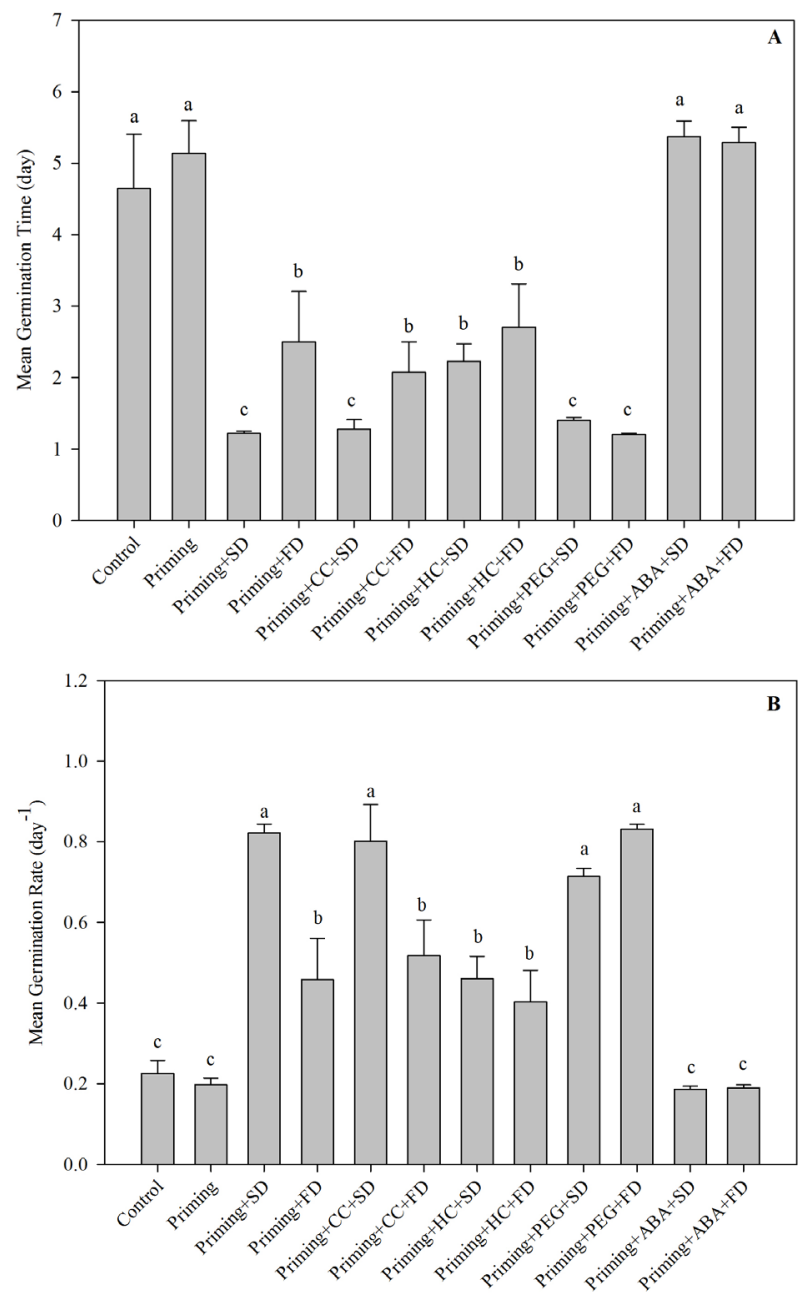

Figure 4: Mean values and standard errors for (A) mean germination time (day) and (B) mean germination rate in melon seeds observed under different conditions. Means were compared by the Scott-Knott test.

\section{CONCLUSIONS}

The results suggest that stress submission subsequent to priming could work promote cross tolerance in melon seeds, maintaining the priming benefits even after drying. Also, slow drying seems more promising than fast drying after priming.

\section{ACKNOWLEDGEMENTS}

This work was supported by CNPq, CAPES, FAPEMIG and Universidade Federal de Lavras.

\section{REFERENCES}

ALVARADO, A.D.; BRADFORD, K.J. Priming and storage of tomato (Lycopersicon lycopersicum) seeds. I. Effects of storage temperature on germination rate and viability. Seed Science and Technology. 16:601-612, $1988 \mathrm{a}$.

Priming and storage of tomato

(Lycopersicon lycopersicum) seeds. II. Influence of a second treatment after storage on germination and field emergence. Seed Science and Technology. 16:613-623, 1988b.

ASHRAF, M.; FOOLAD, M.R. Pre-sowing seed treatment. A shotgun approach to improve germination, plant growth, and crop yield under saline and non-saline conditions. Advances in Agronomy. 88:223-271, 2005.

BAILLY, C. et al. Changes in oligosaccharide content and antioxidant enzyme activities in developing bean seeds as related to acquisition of drying tolerance and seed quality. Journal of Experimental of Botany. 52(357):701-708, 2001.

BAILLY, C. Active oxygen species and antioxidants in seed biology. Seed Science Research.14:93-107, 2004.

BAXTER, A.; MITTLER, R.; SUZUKI, N. ROS as key players in plant stress signaling. Journal of Experimental Botany. 65(1):1-12, 2013.

BITTENCOURT, M.C.C. et al. Efeito do condicionamento osmótico das sementes na germinação e no crescimento de plântulas de Aspargo. Revista Brasileira de Sementes. 26(1):50-56, 2004.

BRAY, C.M. Biochemical processes during the osmopriming of seeds. Seed development and germination. New York: Marcel Dekker, 1995. pp. 767-789.

BUITINK, J. et al. The re-establishment of desiccation tolerance in germinated radicles of Medicago truncatula Gaertn. seeds. Seed Science Research. 13:273-286, 2003.

BUTLER, L.H. et al. Priming and re-drying improve the survival of mature seeds of Digitalis purpurea during storage. Annals of Botany. 103:1261-1270, 2009. 
CANTLIFFE, D. J.; ELBALLA, M. Improved germination of carrot at stressful high temperature by seed priming. In: Proceedings of the Florida State of Horticultural Society. 1994. pp. 121-121.

CATUSSE J.; JOB, C.; JOB, D. Transcriptome and proteome-wide analyses of seed germination. Comptes Rendus Biologies. 331:815-822, 2008.

CHEN, K.; ARORA, R.; ARORA, U. Osmopriming of spinach (Spinaciaoleracea L. cv. Bloomsdale) seeds and germination performance under temperature and water stress. Seed Science \& Technology. 38:45-57, 2010.

CHEN, K.; ARORA, R. Priming memory invokes seed stress-tolerance. Environmental and Experimental Botany. 94:33-45, 2013.

EISVAND, H.R. et al. Effects of hormonal priming and drought stress on activity and isozyme profiles of antioxidant enzymes in deteriorated seed of tall wheatgrass (Agropyron elongatum Host). Seed Science \& Technology. 38:280-297, 2010.

EDELSTEIN, M.; NERSON, H. Low-temperature germination of melon is affected by seedcoat characteristics and embryo genotype. HortScience. 44:1412-1414, 2009.

FARHOUDI, R.; SAEEDIPOUR, S.; MOHAMMADREZA, D. The effect of $\mathrm{NaCl}$ seed priming on salt tolerance, antioxidant enzyme activity, proline and carbohydrate accumulation of Muskmelon (Cucumis melo L.) under saline condition. African Journal of Agricultural Research. 6(6):1363-1370, 2011.

FARIA, J.M.R. et al. Changes in DNA and microtubules during loss and re-establishment of desiccation tolerance in germinating Medicago truncatula seeds. Journal of Experimental Botany. 56(418):2119-2130, 2005.

FAROOQ, M. et al. Osmopriming improves the germination and early seedling growth of melons (Cucumis melo L.). Pakistan Journal of Agricultural Sciences. 44(3):529-536, 2007.

GENOUD, T.; MÉTRAUX, J. Crosstalk in plant cell signaling: structure and function of the genetic network. Trends in Plant Science. 4(12):503-507, 1999.
GIANNOPOLITIS, C.N.; RIES, S.K. Superoxide dismutases. Plant Physiology. 59:309-314, 1977.

HAVIR, E.A.; MCHALE, N.A. Biochemical and developmental characterization of multiple forms of catalase in tobacco leaves. Plant Physiology. 84:450455, 1987.

IBRAF: Comparativo de Exportações de Frutas Frescas. São Paulo, SP: IBRAF, 2012. Available at: <www.ibraf. org.br> Consulted on: 16 Nov. 2013.

KRANNER, I. et al. What is stress? Concepts, definitions and applications in seed science. New Phytologist. 188:655-673, 2010.

LARA, T.S. et al. Potassium nitrate priming affects the activity of nitrate reductase and antioxidant enzymes in tomato germination. Journal of Agricultural Science. 6(2):72-80, 2014.

LIN, R.H. et al. Slow post-hydration drying improves initial quality but reduces longevity of primed bitter gourd seeds. Scientia Horticulturae. 106(1):114-124, 2005.

NAKANO, Y.; ASADA, K. Hydrogen peroxide is scavenged by ascorbate-specific peroxidase in spinach chloroplasts. Plant \& Cell Physiology. 22:867-880, 1981.

NASCIMENTO, W. M.; WEST, S. H. Drying during muskmelon (Cucumis melo L.) seed priming and its effects on seed germination and deterioration. Seed Science and Tecnhology. 28(1):211-215, 2000.

NASCIMENTO, W.M.; ARAGÃO, F.A.S. Condicionamento osmótico de sementes de melão: absorção de água e germinação em diferentes temperaturas. Revista Brasileira de Sementes. 24(1):153-157, 2002.

NASCIMENTO, W.M. Condicionamento osmótico de sementes de hortaliças. Brasília: Embrapa, dez. 2004. 12 p. (Circular Técnica, 33).

Condicionamento osmótico de sementes de hortaliças visando a germinação em condições de temperaturas baixas. Horticultura Brasileira. 23(2):211-214, 2005. 
POWELL, A. A. et al. The influence of aerated hydration seed treatment on seed longevity as assessed by the viability equations. Journal of Experimental Botany. 51(353):2031-2043, 2000.

RANAL, M.A. et al. Calculating germination measurements and organizing spreadsheets. Revista Brasileira de Botanica. 4:849-855, 2009.

SEDGHI, M. Changes in the activity of antioxidant and glyoxylate cycle enzymes of hydro-primed Calendula officinalis (L.) seeds after re-drying temperature stress. Journal of Stress Physiology \& Biochemistry. 9(2):279-286, 2013.

SABEHAT, A.; LURIE, S.; WEISS, D. Expression of small heat-shock proteins at low temperatures: a possible role in protecting against chilling injuries.

Plant Physiology. 117(2) 651-658, 1998.

SLIWINSKA, E.; JENDRZEJCZAK, E. Sugar-beet seed quality and DNA synthesis in the embryo in relation to hydration-dehydration cycles. Seed Science and Technology. 30(3):597-608, 2002.

SOEDA, Y. et al. Gene expression programs during Brassica oleracea seed maturation, osmopriming, and germination are indicators of progression of the germination process and the stress tolerance level. Plant Physiology. 137(1):354-368, 2005.

VIEIRA, C.V. et al. Stress-associated factors increase after desiccation of germinated seeds of Tabebuia impetiginosa Mart. Plant Growth Regulation. 62(3):257-263, 2010. 